\title{
MINERAL RESOURCE POTENTIAL OF THE MOUNT MORIAH ROADLESS AREA, WHITE PINE COUNTY, NEVADA
}

\author{
By \\ Robert R. Carlson and Ronny A. Martin, U.S. Geological Survey, \\ and \\ Robert H. Wood, II, U.S. Burean of Mines
}

\section{STUDIES RELATED TO WHLDERESS}

Under the provisions of the Wilderness Act (Public Law 88-577, September 3, 1964) and related acts, the U.S. Geological Survey and the U.S. Bureau of Mines have been conducting mineral surveys of wilderness and primitive areas. Areas officially designated as "wilderness," "wild," or "canoe" when the act was passed were incorporated into the National Wilderness Preservation System, and some of them are presently being studied. The act provided that areas under consideration for wilderness designation should be studied for suitability for incorporation into the Wilderness System. The mineral surveys constitute one aspect of the suitability studies. The act directs that the results of such surveys are to be made available to the public and be submitted to the President and the Congress. This report discusses the results of a mineral survey of the Mount Moriah Roadless Area (04352), Humboldt National Forest, White Pine County, Nevada. The Mount Moriah Roadless Area was classified as a further planning area during the Second Roadless Area Review and Evaluation (RARE II) by the U.S. Forest Service, January 1979.

\section{MINERAL RESOURCE POTENTIAL SUMMARY STATEMENT}

The U.S. Geological Survey and the U.S. Bureau of Mines made a geologic, geochemical, and mineral survey of the Mount Moriah Roadless Area, east-central Nevada in 1979-81. The area covers 97,205 acres of the Humboldt National Forest in eastern White Pine County, Nevada.

Exposed rocks consist of complexly faulted Paleozoic limestone, dolomite, siltstone, shale, and orthoquartzite emplaced over Cambrian metaquartzite, schist, phyllite, and marble which have been intruded by Cretaceous and (or) Tertiary stocks and sills of monzonite to granodiorite composition.

Production of building stone, lead, silver, zinc, copper, gold, tungsten, and garnet has occurred within or immediately adjacent to the roadless area. Current mining activity within the roadless area consists of the quarrying of an uncommon, high-quality decorative quartzite building stone from an estimated half-trillion tons of reserves on $31 / 2 \mathrm{sq} \mathrm{mi}$ of claims.

A large portion of the Mount Moriah Roadless Area has high potential for additional decorative quartzite building stone resources and low potential for resources of placer and lode garnet abrasive material. Several localities within the roadless area also have moderate or low potential for resources of lead, zinc, silver, and copper. There is no evidence of a potential for oil and gas resources, and as of June 1981, no oil and gas leases or lease applications were on record with the U.S. Bureau of Land Management for the Mount Moriah Roadless Area.

\section{INTRODUCTION}

During the summer of 1979 , and from the fall of 1980 through the summer of 1981 , field investigations were conducted by the U.S. Geological Survey and the U.S. Bureau of Mines to evaluate the mineral resource potential of the Mount Moriah Roadless Area. Field studies included geologic mapping and geochemical sampling by the U.S. Geological Survey and an examination and sampling of mines, prospects, and mineralized areas by the U.S. Bureau of Mines. This report summarizes the findings and includes a mineral resource potential map of the roadless area.
Location, size, and geographic setting

The Mount Moriah Roadless Area covers 97,205 acres of the Humboldt National Forest in eastern White Pine County, Nevada. Located in the northern Snake Range and bounded on the west by Spring Valley and on the east by Snake Valley, the roadless area is 1 $1 / 2 \mathrm{mi}$ from the Utah border, $4 \mathrm{mi}$ north of U.S. Highway 6 and 50, and $35 \mathrm{mi}$ east of Ely, Nevada. The nearest small community is Baker, Nevada, $10 \mathrm{mi}$ to the south (fig. 1).

Elevations in the roadless area range from 6,000 ft along its eastern edge and 7,000 ft for much of the 


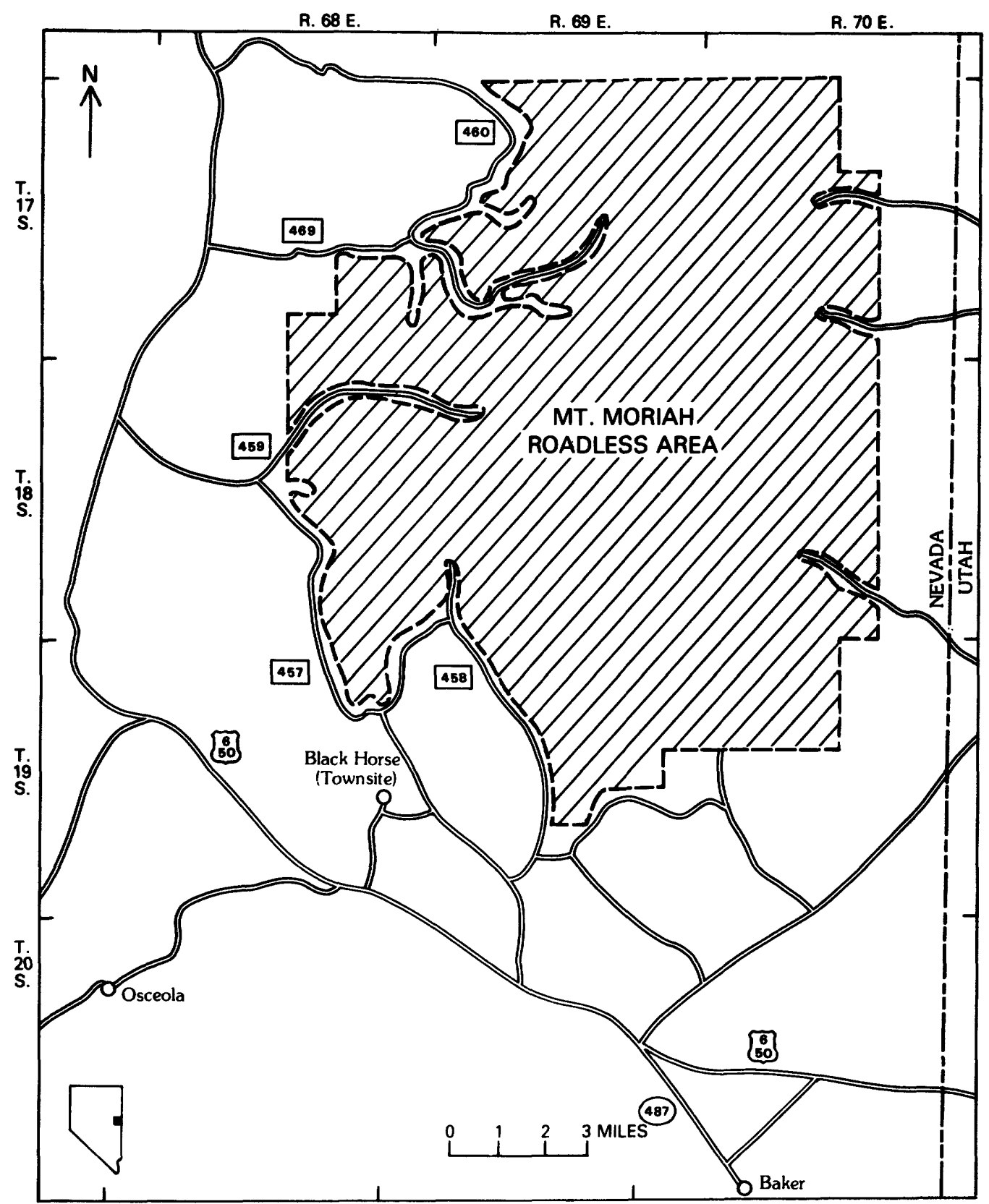

Figure 1.-Index map showing location of the Mount Moriah Roadless Area, Nevada. 
western edge to $12,050 \mathrm{ft}$ on the summit of Moumt Moriah, the only named peak in the area. The topography varies from a high plateau $(8,000-9,000 \mathrm{ft}$ in elevation) in the northwest to deep canyons flanked by 2,000-ft cliffs in the central and eastern portions of the roadless area. Most streams are intermittent and show signs of spasmodic flash flooding. Vegetation ranges from cacti, desert shrubs, and scrub trees to thick stands of conifers and tall deciduous trees.

Access to the interior of the roadless area is provided by numerous U.S. Forest Service and unmaintained roads, many of which are washed out or require rough-terrain vehicles.

\section{Geologic setting}

The area is divided into two major geologic terranes by the Snake Range décollement, a slightly warped, low-angle to flat-lying fault. Bedded rocks below the fault consist of Proterozoic $Z$ to Middle Cambrian metaquartzite, schist, phyllite, and marble. These rocks were intruded in the Late Cretaceous and (or) Tertiary by stocks and sills of monzonite to granodiorite composition that produced the garnetgrade metamorphism of the bedded rocks. Much cataclasite and mylonite are present in the lower plate rocks, but, except for a lesser decollement, faulting is almost absent. The upper plate rocks (rocks above the Snake Range décollement) range in age from Middle Cambrian to Permian and consist of limestones, dolomites, siltstones, shales, and orthoquartzites. These rocks are unmetamorphosed but are structurally complex due to much high- and low-angle faulting. These faults terminate at the décollement.

Formations below the Snake Range décollement include, in ascending stratigraphic order, the McCoy Creek Group of Misch and Hazzard (1962), Prospect Mountain Quartzite, Pioche Shale, Pole Canyon Limestone, Lincoln Peak Formation, and Dunderberg Shale. The contact between the Pioche Shale and the Pole Canyon Limestone is generally a low-angle fault (the lesser décollement previously mentioned) which is cut in many places by the Cretaceous or Tertiary granitic intrusives. Proterozoic rocks of the McCoy Creek Group do not crop out in the roadless area.

Formations above the Snake Range décollement include, in ascending stratigraphic order, the Pole Canyon Limestone, Lincoln Peak Formation, Dunderberg Shale, Notch Peak Formation, Pogonip Group, Eureka Quartzite, Fish Haven Dolomite, Laketown Dolomite, Sevy Dolomite, Simonson Dolomite, Guilmette Limestone, Pilot Shale, Joana Limestone, Chainman Shale, Ely Limestone, Riepe Spring Limestone of Steele (1960), and Arcturus Formation (Hose, 1981).

\section{Mining activity}

Past production in or near the roadless area included the following: building stone, lead, silver, zinc, copper, gold, tungsten, and garnet. Decorative quartzite building stone is produced within the roadless area from many small quarries south of the lower reaches of Hendrys Creek and between Hendrys Creek and Hampton Creek. A small quarry north of the Silver Peak mine in upper Smith Creek also showed recent (1981) signs of building stone production. Signs of recent prospecting activity and claim staking for metallic minerals were observed near Old Man's Canyon just outside the southern border of the roadless area.

\section{GEOLOGY, GEOCHEMISTRY, AND GEOPHYSICS}

In general, the types of resources in the roadless area are characterized by their occurrence in either the lower or upper plate rocks. Resources in the lower plate rocks appear to be limited to building stone and garnet abrasives that owe their origin to metamorphism of the lower plate. The building stone is produced from strongly foliated metaquartzite beds of the Prospect Mountain Quartzite. The garnets are abundant in thick beds of muscovite schist in the Prospect Mountain Quartzite.

Resources above the Snake Range décollement appear to be associated with faulting in the upper plate units and consist of concentrations of lead, zinc, copper, and silver minerals along shear zones. Shear zones and associated metal concentrations that extend to depth terminate at the Snake Range décollement. One known exception to the separation of resource types by the Snake Range décollement is a lead-silver replacement deposit (Silver Peak mine) at the sheared base (the previously mentioned lesser décollement) of a small klippe of lower plate, metamorphosed Cambrian limestone.

The geochemical study of the roadless area included emission spectrographic analysis of 347 stream-sediment, heavy-mineral concentrate, rock, and placer samples collected from within and adjacent to the roadless area. Magnetic separation of each heavy-mineral concentrate produced three fractions: a magnetic fraction containing mostly magnetite, ilmenite, and hematite; a semimagnetic fraction containing mostly amphiboles, pyroxenes, and garnets; and a nonmagnetic fraction containing heavy accessory minerals and most ore minerals. Analyses of the nonmagnetic fractions showed some drainages with anomalously high values of lead, zinc, copper, and barium. Analytical values for these fractions were as high as 10,000 ppm (parts per million) lead (background values ranged from 20 to $300 \mathrm{ppm}$ ), 5,000 ppm zinc (background values ranged from less than $500 \mathrm{ppm}$ to $500 \mathrm{ppm}$ ), $500 \mathrm{ppm}$ copper (background values ranged from less than $10 \mathrm{ppm}$ to $10 \mathrm{ppm}$ for lower plate rocks and 20 to $150 \mathrm{ppm}$ for upper plate rocks), and 7,000 ppm barium (background values ranged from 30 to $2,000 \mathrm{ppm}$ ). In most cases, the anomalous values occurred in panned concentrates from streams draining areas of upper plate rocks, the major exception being high lead values from the drainage below the lower plate Silver Peak mine.

The garnet content of each semimagnetic fraction of the heavy-mineral concentrates was microscopically determined and put into one of the following categories: (1) no garnet content; (2) 1-33 percent garnet content; (3) 34-66 percent garnet content; and (4) greater than 66 percent garnet content. Results of these microscopic observations were compared with the garnet content of a sample taken in Hampton Creek below an area of past placer garnet mining. The garnet content of this control sample fell into the 34-66 percent category. Most streams draining exposures of the Prospect Mountain Quartzite in the lower plate showed garnet abundances of 34 to 66 percent by volume in the semimagnetic 
fraction and many of these samples showed abundances greater than 66 percent.

Analyses of rock samples collected from mines, prospects, and mineralized zones in and adjacent to the roadless area, almost all of which are in upper plate rocks, showed some anomalous values for zinc, lead, copper, silver, antimony, arsenic, and barium; highest values were 25 percent zinc, 10 percent lead, 2 percent copper, 0.05 percent silver, 0.15 percent antimony, 0.5 percent arsenic, and 19 percent barium.

A low-altitude magnetic survey was drape-flown over the topography at $1,000 \mathrm{ft}$ to detect shorter wavelength anomalies. The aeromagnetic data show little correlation with the exposed geology and they possibly delineate magnetic sources which occur in the lower plate rocks. A broad magnetic high occurs along the west side of the roadless area and appears to have two east- and southeast-trending offshoots, the southernmost of which is over an exposed granitic intrusive body in the lower plate. It is assumed that the magnetic highs are caused by this granitic intrusive rock, which is not only buried beneath the upper plate rocks, but also, in places, is concealed beneath the exposed lower plate rocks. The aeromagnetic data do not appear to relate directly to known mineralized areas in the roadless area.

\section{MINING DISTRICTS AND MINERALTZED AREAS}

The Mount Moriah Roadless Area includes parts of two adjacent mining districts: the Mount Moriah mining area, which covers all but the southwestern corner, and the Black Horse mining district, which covers the southwestern corner.

\section{Mount Moriah mining area}

This area is named for several unrelated mine workings and prospects on and around Mount Moriah (Hose and others, 1976). Mining areas discussed below that occur within the roadless area are (1) Hampton Creek, (2) Prospect Mountain Quartzite, (3) Trail Canyon, (4) Mount Moriah, (5) Silver Peak mine, and (6) Smith Creek. Those just outside the roadless area are (1) Galena mine, and (2) Hendrys Creek.

\section{Hampton Creek area}

Industrial almandine garnets occur in a small-scale, low-concentration placer deposit along the valley floor of Hampton Creek. Placer claims on the deposit extend from about $1 \mathrm{mi}$ outside to approximately $31 / 2 \mathrm{mi}$ inside the roadless area. In addition, lode mining claims have been staked over the upper $11 / 2 \mathrm{mi}$ of placer claims on a garnetiferous mica-schist in the Prospect Mountain Quartzite (the source for the placer deposits). The remains of a gravity-type mill that was constructed in 1963 for purposes of recovering the placer garnets were noted, and a 67-ft by 32-ft pit in the channel alluvium was sampled during field investigations (Wood, 1983).

\section{Prospect Mountain Quartzite area}

Excellent quartzite decorative building stone has been quarried from over 50 small- to medium-size quarries within and adjacent to the southeastern portion of the roadless area. Other mining claims and (or) quarrying operations for this stone are located in Negro Creek and in the upper reaches of Smith Creek and Deadman Creek. The quartzite is used as dimension building stone, flagstone, and artistic mosaic and sculpture stone. The actively mined Richard Hatch claims in the southeast part of the roadless area cover $31 / 2 \mathrm{sq} \mathrm{mi}$ within the roadless area and $2 \mathrm{sq} \mathrm{mi}$ outside the area. The colors and shapes of the quartzite vary widely from quarry to quarry, and the most sought-after stone comes from the more westerly quarries, which occur within the roadless area.

\section{Trail Canyon area}

Mineralized (malachite and unidentified silver minerals) upper plate Laketown and Fish Haven Dolomites are explored by two short adits near the intersection of a northeast-trending high-angle fault and a low-angle fault. The adits are located about 3 mi inside the roadless area, 1/2 mi south of Negro Creek in Trail Canyon. The copper-silver mineralization occurs along bedding planes, but was not traced on the surface beyond the area of the workings. It is not known whether mineralization continues at depth, either with the bedding-plane association or with one of the nearby faults.

\section{Mount Moriah area}

Copper-stained vein quartz (malachite and azurite) is found on the dumps of two of the prospects on the east side of the Mount Moriah summit. The quartz veins do not crop out, but are possibly associated with a northwest-trending fault zone in upper plate Cambrian limestone. Analyses of the quartz vein material from the dumps and a 4-ft chip sample across the fault (which is exposed in the upper prospect) showed elevated silver and copper values in both materials (V. T. Dow, U.S. Forest Service, unpub. data, 1969; Wood, 1983). Mineralized rock was not seen beyond these small, caved workings.

\section{Silver Peak mine area}

The Silver Peak mine workings are in the upper reaches of Smith Creek, just inside the roadless area. A small, replacement-type, lead-silver deposit at the sheared base of a klippe of metamorphosed Cambrian limestone (mapped as lower plate rock, Hose, 1981) was mined. Although the geologic setting is similar for the rest of the 1/2-mi-diameter klippe, mineralization was not traced on the surface beyond the area of the workings, and no lead-silver anomalies were detected by stream-sediment geochemistry for other than the Silver Peak mine.

\section{Smith Creek area}

Near the mouth of Smith Creek, in the northeast corner of the roadless area, two small adits were driven into a narrow northwest-trending fault zone in upper plate Cambrian limestone. Barite and small amounts of silver occur in the fault zone, but mineralization was not traceable beyond the workings (Wood, 1983). 
Galena mine area

Mine workings variously referred to as the Galena, Monitor Gulch, or Kaufman mine are located 1/3 mi east of the roadless area between Smith Creek and Horse Canyon. Samples from this replacementtype deposit in upper plate Notch Peak Limestone showed elevated levels of zinc and lead with minor silver (Wood, 1983).

Hendrys Creek area

A small deposit of mineralized rock along westand south-trending fault zones is explored by three short adits and several shallow pits and bulldozer cuts on and near a small hill about 1 mi east of the roadless area. The host rocks are Ordovician limestone mapped as combined Eureka Quartzite and Pogonip Group by Hose and others (1976). Galena, barite, and malachite were identified in this deposit, and analyses showed elevated levels of lead, barium, and silver in a select sample. The fault system associated with this small deposit does not appear to extend into the roadless area (Wood, 1983).

\section{Black Horse mining district}

Most of the Black Horse district is outside of the study area to the south and southwest; and all production was outside the study area. Commodities produced were 4,655 oz gold, 4,535 oz silver, 38,948 lb lead, 337 short ton units of tungsten, $179 \mathrm{lb}$ copper, and $44 \mathrm{lb}$ zinc (Hose and others, 1976). Mining activity has occurred at three places in the Black Horse mining district: (1) the Black Horse workings, (2) the Bellander mine, and (3) the Tilford mine.

Black Horse workings

Starting in 1905, mining near the town of Black Horse (about $2 \mathrm{mi}$ southwest of the roadless area) produced gold and, later, scheelite from northeast-striking quartz-calcite veins along bedding-plane faults in Cambrian limestone (Hose and others, 1976). These fault-related veins do not appear to extend into the roadless area.

Bellander mine

Located $2 \mathrm{mi}$ south of the roadless area, the Bellander mine produced lead-silver ore from manganese- and iron-stained pods in Tertiary conglomerate. The pods occur along a north-striking, west-dipping fault (Hose and others, 1976). Iron-stained Tertiary rocks occur in the roadless area near the southeast corner, but samples from small prospects in this area did not contain detectable lead or silver (Wood, 1983).

Tilford mine

The Tilford, or Anna Lee, mine is located on a steep western slope of Silver Creek adjacent to a southwestern re-entrant into the roadless area. Silver ore was produced from an area containing numerous small faults and an iron- and copper-stained calcite vein (Hose and others, 1976). A sample from this mine, containing calcite fracture fillings in upper plate
Cambrian limestone, showed elevated values for silver, copper, lead, and zinc (R. R. Carlson, unpub. data, 1983). The faults were not traced into the roadless area.

\section{ASSESSMENT OF MINERAL RESOURCE POTENTIAL}

The assessment of the mineral resource potential of the Mount Moriah Roadless Area is based on geologic controls as defined by the structural and stratigraphic settings; geochemical data from stream-sediment, heavy-mineral concentrate, rock, and placer samples; observed mineral occurrences in mines, prospects, and placers; and records of current and historical quarrying. Geophysical evidence suggests the existence of additional granitic intrusive bodies in the lower plate, hidden below the upper plate rocks. No known mineralization is associated with the exposed granitic rocks in the area, and, therefore, is not expected to be associated with these covered granitic bodies, either.

\section{Decorative building stone}

A high-quality quartzite building stone is currently quarried from claims in the southeastern portion of the roadless area. This uncommon decorative building stone is in the metamorphosed Prospect Mountain Quartzite; current claims on this unit cover over $31 / 2 \mathrm{sq} \mathrm{mi}$ of the roadless area and contain an estimated half-trillion tons of stone (fig. 2). Adjacent to these claims, outside the roadless area to the east, is an area of over $2 \mathrm{sq} \mathrm{mi}$ of claims that contain additional resources of decorative stone of lower quality (Richard Hatch, claim owner, oral commun., 1981, 1983). The building stone resource is shown as area $A$ in figure 2.

A large exposure (fig. 2, area B) of lower plate rocks in the roadless area contains additional quantities of this quartzite (mapped by Hose, 1981, as combined Pioche shale and Prospect Mountain Quartzite). Small amounts of the stone have been quarried in the north-central portion of the roadless area and dimension-stone quartzite was observed cropping out elsewhere in area $B$.

\section{Gamet abrasives}

Garnet-bearing schists in the Prospect Mountain Quartzite are the source for garnet placer deposits mined in Hampton Creek in the 1960's (Hose and others, 1976). Lode and placer claims have been staked on the schist and stream gravels for $31 / 2 \mathrm{mi}$ up Hampton Creek in the roadless area (fig. 2, area C). High gamet content in panned concentrates, coupled with the mapped surface geology (Hose, 1981), broadens the areas with potential for placer and lode occurrences to areas $A$ and $B$. However, the high content of magnetite inclusions within the garnet crystals, together with the relatively low garnet content of the rocks and placers (4-20 percent of total rock or placer concentration), could make these areas less favorable for ganet abrasive resources.

Lead, zinc, silver, and copper

Most lead, zinc, silver, and copper mineralization 5 

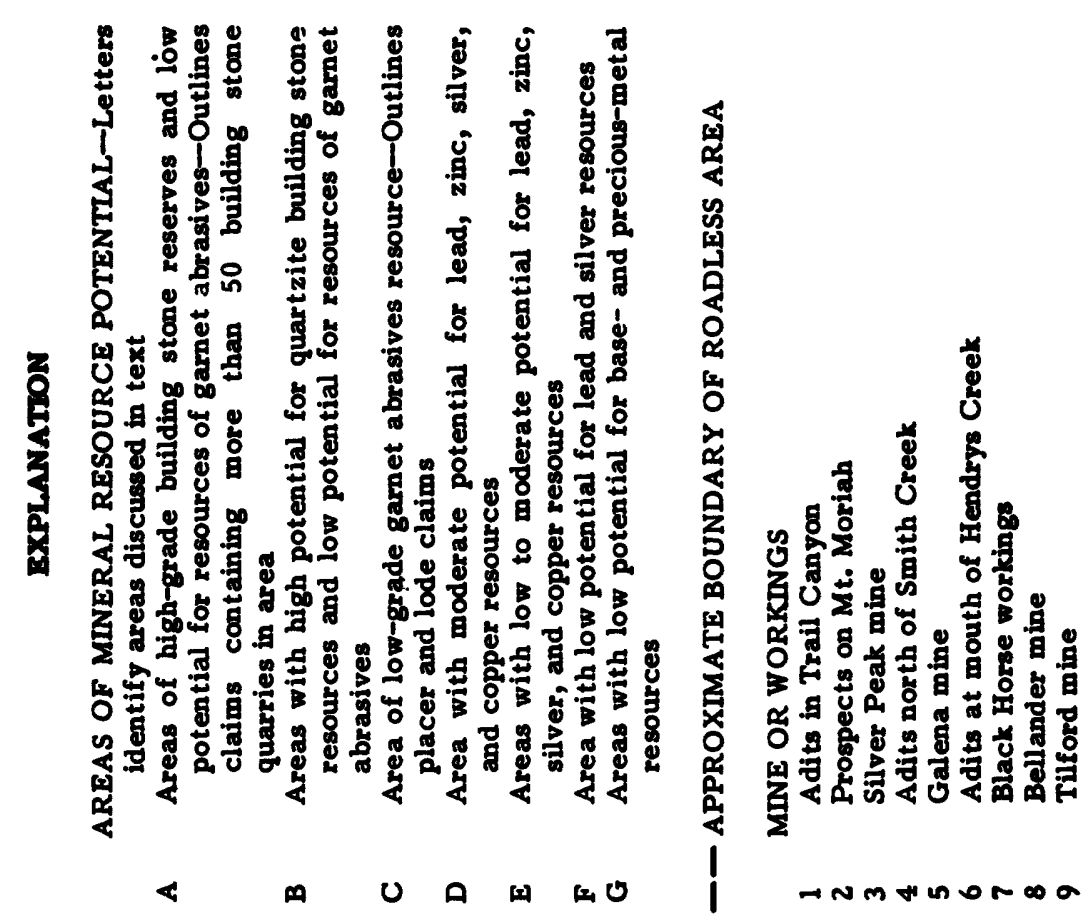

昫

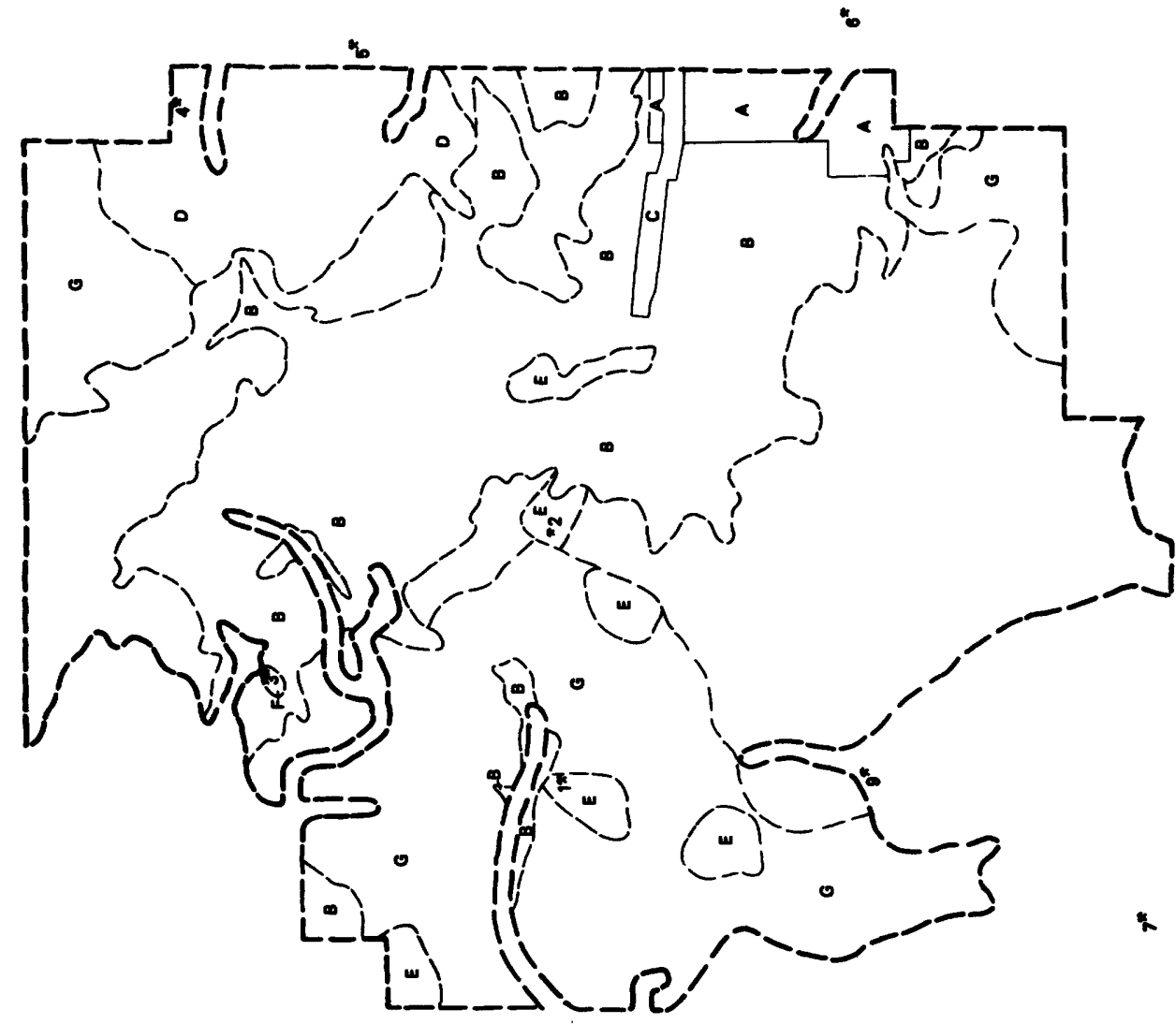

章 
high-angle faults in the upper plate rocks. It is here postulated that the few occurrences of mineralization in low-angle faults or along bedding planes in the area resulted from their intersections with high-angle faults, which acted as conduits for mineralizing fluids. Considering the near lack of high-angle faults in the exposed lower plate rocks, and the observed termination of upper plate high-angle faults against the Snake Range décollement, mineralization of the upper plate rocks must have occurred prior to emplacement in their present setting. This severely limits the depth of possible upper plate deposits, because mineralization in a high-angle fault would terminate at the décollement separating the two plates. One known exception to the confinement of base- and precious-metal minerals to the upper plate rocks is a lead-silver occurrence in a low-angle fault (the previously mentioned lesser décollement) below a small klippe of lower plate, metamorphosed Pole Canyon Limestone (at the Silver Peak mine).

A moderate potential for base- and precious-metal resources exists in the northeastern part of the roadless area (fig. 2, area D). Thirty-three tons of lead-zinc ore containing minor silver and copper were extracted from the Galena mine, just outside the roadless area south of lower Smith Creek, and an equal amount of ore is estimated to be present in the mine. The proximity of the Galena mine, the geochemical evidence (highly anomalous lead and zinc values in panned concentrates), and mineralization observed in a small adit north of lower Smith Creek indicate that the mineralizing system extends into the roadless area.

Scattered areas (fig. 2, areas E) have low to moderate potential for resources of base and precious metals. Favorable evidence includes the occurrence of highly faulted upper plate rocks and either the previously discussed showings of lead, zinc, silver, or copper minerals in outcrops and prospects or elevated values for combinations of these elements in panned concentrates.

Area F (fig. 2), which contains the klippe in which the Silver Peak mine is located, has a low potential for additional resources of lead and silver. The geologic setting for the rest of the klippe is similar to that for the Silver Peak mine, but no lead-silver anomalies were detected geochemically for other than the Silver Peak mine and mineralization was not seen beyond the area of the workings.

Four areas (fig. 2, areas G) have low potential for resources of base and precious metals. These areas are in the highly faulted upper plate rocks, which are favorable terrane. However, only slightly anomalous values of copper in panned concentrates were detected; values of $20-150 \mathrm{ppm}$ were found in these areas compared with background values for the upper plate rocks of $10-10 \mathrm{ppm}$.

\section{Barium}

Several scattered drainages showed geochemical anomalies for barium, but the only observed sources were small veins and fracture fillings of secondary barite associated with fault zones. No sedimentary occurrences of barite or barite interbeds in gypsum have been reported.

\section{Oil and gas}

As of June 1981, no oil and gas leases or lease applications have been filed within the roadless area boundaries, although several leases were current in valleys surrounding the area. There is no evidence of a potential for oil and gas resources within the roadless area.

\section{REFERENCES}

Hose, R. K., 1981 [1982], Geologic map of the Mount Moriah Further Planning (RARE II) Area, eastern Nevada: U.S. Geological Survey Miscellaneous Field Studies Map MF-1244-A, scale 1:62,500.

Hose R. K., Blake, M. C., and Smith, R. M., 1976, Geology and mineral resources of White Pine County, Nevada: Nevada Bureau of Mines and Geology Bulletin 85, 105 p.

Misch, Peter, and Hazard, J. C., 1962, Stratigraphy and metamorphism of Late Precambrian rocks in central northeastern Nevada and adjacent Utah: American Association of Petroleum Geologists Bulletin, v. 46, no. 3, p. 289-343.

Steele, Grant, 1960, Pennsylvanian-Permian stratigraphy of east-central Nevada and adjacent Utah, in Geology of east-central Nevada: Intermountain Association of Petroleum Geologists and Eastem Nevada Geological Society Guidebook, 11th Annual Field Conference, Salt Lake City, p. 91-113.

Wood, R. H., 1983, Mineral investigation of the Moumt Moriah Roadless Area, White Pine County, Nevada: U.S. Bureau of Mines Open-File Report MLA $50-83,27$ p. 
1

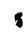

